\title{
APLIKASI TIGA JENIS PUPUK ANORGANIK TERHADAP PERTUMBUHAN DAN \\ HASIL TIGA VARIETAS CABAI HIBRIDA UNIB (Capsicuum annuum L.)
}

Three Types Of Anorganic Fertilizer Applications Toward Growth And Three Results

Of Unib Hybrid Variety (Capsicum annum L.)

\author{
Andi Tri Maryono1), Dwi Wahyuni Ganefianti*1), Bambang Gonggo Murcitro ${ }^{2)}$, \\ Rustikawati $^{1)}$, Herry Gusmara ${ }^{1)}$, Mukhtasar ${ }^{1)}$, Umi Salamah ${ }^{1)}$ \\ ${ }^{1)}$ Program Studi Agroekoteknologi, Fakultas Pertanian Universitas Bengkulu. \\ ${ }^{2)}$ Program Studi Ilmu Tanah, Fakultas Pertanian Universitas Bengkulu. \\ *) e-mail: dw_ganefianti@unib.ac.id
}

\begin{abstract}
ABSTRAK
Penggunakan benih lokal yang ditanam secara terus menerus telah menyebabkan produksi rendah. Upaya untuk meningkatkan produktivitas cabai yaitu dengan menggunakan benih hibrida unggul yang memiliki produktivitas yang tinggi, umur panen genjah, memiliki daya tahan terhadap hama dan penyakit, dan buah yang disukai para konsumen serta daya adaptasi lingkungan yang tinggi. Rancangan Percobaan yang digunakan adalah Rancangan Acak Lengkap (RAL) pola faktorial, yang terdiri atas 2 faktor. Faktor pertama adalah jenis pupuk terdiri atas 3 jenis yaitu : NPK Mutiara $(16: 16: 16)=300 \mathrm{~kg} / \mathrm{ha}$, Urea+KCl+TSP $=250$ $\mathrm{kg} / \mathrm{ha}+500 \mathrm{~kg} / \mathrm{ha}+400 \mathrm{~kg} / \mathrm{ha}, 1 / 2$ dosis Urea $+1 / 2$ dosis $\mathrm{KCl}+1 \frac{1}{2}$ dosis $\mathrm{TSP}+1 / 2$ dosis NPK Mutiara $(16: 16: 16)=125 \mathrm{~kg} / \mathrm{ha}+250 \mathrm{~kg} / \mathrm{ha}+200 \mathrm{~kg} / \mathrm{ha}+150 \mathrm{~kg} / \mathrm{ha}$. Faktor kedua adalah Varietas cabai hibrida terdiri atas 3 varietas yaitu : UNIB C H73, UNIB C H65 dan, UNIB C H13. Dari kedua faktor tersebut diperoleh 9 pasang perlakuan, diulang 5 kali sehingga diperoleh 45 satuan percobaan, yang terdiri atas 2 tanaman sehingga didapatkan 90 tanaman.Hasil penelitian menunjukkan bahwa aplikasi pupuk anorganik urea+KCl+TSP menghasilkan jumlah buah total tertinggi pada varietas UNIB C H65. Aplikasi pupuk anorganik Urea+KCl+TSP menghasilkan tinggi tanaman yang lebih tinggi dari aplikasi pupuk anorganik lainnya, dengan umur berbunga yang lebih cepat dibandingakan aplikasi pupuk anorganik lainnya. Aplikasi pupuk anorganik pada varietas UNIB C H73 menghasilkan diameter batang lebih besar, umur panen yang relatif cepat, panjang tangkai buah lebih panjang, panjang buah terpanjang dan bobot buah segar terberat dibandingkan varietas lainnya.
\end{abstract}

Kata kunci: cabai; pupuk anorganik

\section{ABSTRACT}

The use of locally grown seeds has led to low production. That the hybrid seed is high production, early harvesting, resistant of disease, high adaptability to the environment, and preferred by consumers, the experimental design used was a Completely Randomized Design (CRD) factorial pattern that is consisting of 2 factors. The first factor is the type of fertilizer consisting of 3 types, namely: NPK Mutiara $(16: 16: 16)=300 \mathrm{~kg} / \mathrm{ha}$, Urea $+\mathrm{KCl}+$ $T S P=250 \mathrm{~kg} / \mathrm{ha}+500 \mathrm{~kg} / \mathrm{ha}+400 \mathrm{~kg} / \mathrm{ha}, 1 / 2$ dose of Urea $+1 / 2$ dose of $\mathrm{KCl}+1 / 2$ dose of TSP + 1/2 dose of NPK Pearl $(16: 16: 16)=125 \mathrm{~kg} / \mathrm{ha}+250 \mathrm{~kg} / \mathrm{ha}+200 \mathrm{~kg} / \mathrm{ha}+150 \mathrm{~kg} / \mathrm{ha}$. The second factor is the hybrid chili varieties consisting of 3 varieties, namely: UNIB C H73, UNIB C H65, and, UNIB C H13. From these two factors, nine pairs of treatments were obtained that repeated five times to obtain 45 experimental units. The result showed that the application of urea $+\mathrm{KCl}+\mathrm{TSP}$ inorganic fertilizer produced the highest total number of fruits in the UNIB C H65 variety. Application of inorganic fertilizer Urea $+\mathrm{KCl}+\mathrm{TSP}$ produces a higher plant height than other inorganic fertilizer applications, with a faster flowering age compared to other inorganic fertilizer applications. The application of inorganic fertilizer on UNIB C H73 variety produced a larger stem diameter, relatively fast 
harvesting age, longer fruit stalk length, longest fruit length, and heaviest fresh fruit weight compared to other varieties.

Keywords: Chili paper;inorganic fertilizer

\section{PENDAHULUAN}

Cabai (Capsicum annuum L.) merupakan tanaman hortikultura potensial yang mempunyai nilai ekonomi dan permintaan pasar yang tinggi. Cabai banyak digunakan sebagai bahan baku industri, pangan, dan farmasi. Pemasaran cabai dapat dilakukan dalam bentuk segar, kering, bubuk sebagai bahan dasar industri maupun dalam bentuk pasta cabai. Cabai mengandung protein, lemak, karbohidrat, kalsium $(\mathrm{Ca})$, fosfor $(\mathrm{P})$, besi $(\mathrm{Fe})$, vitamin, senyawa kapsaisin, dan kapsisidin (Harpenas dan Dermawan, 2010).

Berdasarkan data dari Pusat Data dan Sistem Informasi Pertanian (2016) produktivitas cabai di Indonesia mengalami peningkatan $2,06 \%$ dalam dua tahun terakhir. Data Kementerian Pertanian pada tahun 2015, tercatat produktivitas cabai di Indonesia mencapai 8,65 ton/ha. Namun pada tahun 2016 produktivitas cabai tersebut mengalami penurunan $0.2 \%$ dari produktivitas tahun 2015, dengan produktivitas sebesar 8,45 ton/ha. Jika dibandingkan dengan skala Internasional, produktivitas cabai di Indonesia masih sangat jauh lebih rendah dibandingkan negara China yang mencapai $\pm 22,30$ ton/ha dengan luasan panen sebesar 130,856 hektar (Pusat Data dan Sistem Informasi Pertanian, 2016).

Rendahnya tingkat produktivitas cabai di Indonesia disebabkan oleh banyaknya petani yang masih sering menggunakan varietas lokal. Pemilihan varietas lokal oleh petani karena mudah didapat, tetapi memiliki daya produksi yang rendah (Widiyono dan Hidayanti, 2005). Dibandingkan dengan negara China produktivitas cabai di Indonesia tertinggal jauh. Mayoritas para petani di Chinatelah menggunakan varietas unggul yang dikenal dengan hibrida (hybrid). Cabai hibrida merupakan cabai hasil turunan pertama (F1) dari suatu persilangan sepasang atau lebih tetua (galur murni) yang mempunyai sifat unggul (Tarigan dan Wiryanta, 2007). Universitas Bengkulu melalui serangkaian penelitian telah merakit sejumlah hibrida diantaranya adalah UNIB C H13, UNIB C H23 dan, UNIB C H73 (Ganefianti et al., 2017). Ketiga varietas tersebut mempunyai rata-rata produktivitas yang dikategorikan tinggi yaitu 7 - 13 ton/ha (Febriansyah,2013).

Selain penggunaan varietas unggul, peningkatan produktivitas suatu tanaman dapat dibarengi dengan pemupukan (Mulyani dan Kartasapoetra, 2002). Pemupukan tanaman dilakukan dengan cara memberikan pupuk organik dan anorganik. Pupuk anorganik diketegorikan dalam 2 jenis yaitu pupuk anorganik tunggal dan pupuk anorganik majemuk (Raziliano et.al, 2015). Akhir-akhir ini kecenderungan petani dan peneliti menggunakan 
pupuk majemuk lebih tinggi dibandingkan dengan penggunaan pupuk tunggal. Padahal pemberian pupuk tunggal pada tanaman mampu meningkatkan produktivitas tanaman. Alasan yang dikemukakan adalah kemudahan mendapatkannya, lebih ekonomis dan pengaplikasiannya yang lebih mudah.

Beberapa penelitianmenggunakan pupuk anorganik telah menunjukkan hasil yang optimal. Penelitian Febriansyah (2013) dan Siregar (2014) pada cabai yang dipupuk menggunakan pupuk anorganik majemuk NPK Mutiara (16:16:16) dosis 2 - 5 g/tanaman dapat meningkatkan bobot total buah sebesar 381,17 - 707,56 g/tanaman (6 - 14 ton/ha). Prasetya (2014) menyatakan bahwa pemberian pupuk anorganik majemuk NPK Mutiara (16:16:16) sebanyak $300 \mathrm{~kg} / \mathrm{ha}$ dengan kombinasi pupuk kandang sebesar 5 ton/ha dapat meningatakan bobot buah total rata-rata sebesar $102 \mathrm{~g} /$ tanaman. Hasil penelitian menggunakan pupuk anorganik tunggal yang dilakukan oleh Sirappa dan Senewa(2014) menunjukkan bahwa pemberian pupuk anorganik tunggal N (Urea) $150 \mathrm{~kg} / \mathrm{ha}, \mathrm{N}$ (ZA) 400 $\mathrm{kg} / \mathrm{ha}, \mathrm{P}$ (SP-36) $200 \mathrm{~kg} / \mathrm{ha}$, dan $\mathrm{K}(\mathrm{KCl}) 100 \mathrm{~kg} / \mathrm{ha}$, memberikan produksi tanaman cabai mencapai 24,59 ton/ha. Raziliano et al. (2015) menyatakan bahwa pemberian pupuk anorganik Urea, TSP, dan $\mathrm{KCl}$ dengan dosis $250 \mathrm{~kg} / \mathrm{ha}$ (100 g/plot), 500 kg/ha (200 g/plot), $400 \mathrm{~kg} / \mathrm{ha}$ (160 g/plot) dapat meningkatkan bobot buah segar cabai sebesar 236,05 g/tanaman. Penggunaan pupuk anorganik tunggal dapat meningkatkan produksi tanamandengan perbandingan komposisi pupuk yang berbeda-beda.

Varietas cabai hibrida hasil rakitan pemulia Universitas Bengkulu akan menjadi daya dorong untuk meningkatkan produktivitas tanaman. Pemberian pupuk yang sesuai tentu akan mendukung upaya ini. Penelitian ini betujuan untuk mendapatkan interaksi antara pupuk anorganik dan varietas cabai hibrida UNIB, mendapatkan informasi pertumbuhan dan hasil tanaman cabai hibrida UNIB pada setiap jenis pupuk anorganik.

\section{METODE PENELITIAN}

Penelitian ini telah dilaksanakan dalam bentuk percobaan pot dengan menggunakan polybag pada bulan Juni sampai dengan Oktober 2018 di screen house (rumah kawat) yang berlokasi di Perumahan DIKNAS Kelurahan Surabaya Kecamatan Sungai Serut Kota Bengkulu, dengan ketinggian tempat $10 \mathrm{~m}$ dpl. Penelitian ini menggunakan Rancangan Acak Lengkap (RAL) pola faktorial yang terdiri atas 2 faktor. Faktor pertama adalah jenis 3 jenis pupuk $(\mathrm{P})$ yaitu : $\mathrm{P}_{1}(\mathrm{NPK}$ Mutiara $(16: 16: 16)=300 \mathrm{~kg} / \mathrm{ha}), \mathrm{P}_{2}(\mathrm{Urea}+\mathrm{KCl}+\mathrm{TSP}=250$ $\mathrm{kg} / \mathrm{ha}+500 \mathrm{~kg} / \mathrm{ha}+400 \mathrm{~kg} / \mathrm{ha}), \mathrm{P}_{3}(1 / 2$ dosis Urea $+1 / 2$ dosis $\mathrm{KCl}+1 / 2$ dosis TSP $+1 / 2$ dosis NPK Mutiara 16 : $16: 16)$ setara125 kg urea/ha+250 kg KCl/ha+200 kg TSP/ha+150 kg NPK Mutiara (16:16:16)/ha. Faktor kedua adalah varietas cabai hibrida (V) terdiri atas 3: $\mathrm{V}_{1}$ 
(UNIB C H73 ), $\mathrm{V}_{2}$ (UNIB C H65) dan $\mathrm{V}_{3}$ (UNIB C H13). Dari kedua faktor tersebut diperoleh 9 pasang perlakuan, yang diulang sebanyak 5 kali, sehingga diperoleh 45 satuan percobaan yang dibuat 2 unit percobaan lapangan sehingga didapatkan 90 tanaman.

Tahapan awal penelitian adalah persiapan benih.Benih cabai direndam ke dalam air selama 1 menit untuk mengetahuikelayakan benih. Benih yang layak akan terlihat mengendap ke bawah dan benih yang mengapung adalah benih yang telah rusak. Benih yang mengendap ditiriskan di atas nampan/telanan untuk dikeringkan selama 5 menit. Benih yang telah kering dikecambahkan menggunakan metode uji kertas kertas gulung dengan cara meletakan benih dalam kertas atau tisu basah di dalam nampan dan didiamkan selama 7 hinggaterbentuk radikula. Metode ini dilakukan untuk mengetahui persentase daya kecambah benih. Benih yang telah memiliki radikula dipindahkan ke dalam tray semai yang berisi tanah top soil dan pestisida berbahan aktif karbofuran 3\%selama 21 hari.

Persiapan media tanam dilakukan dengan cara mengambil tanah pada lahan praktikum rempah dan obat, sebanyak $810 \mathrm{~kg}$. Media tanam ini kemudian dianalisis untuk menentukan kadar air, pH, bahan organik, N, P dan, K pada tanah. Media diberikan penambahan kapur dolomit sebanyak 2,25 $\mathrm{kg}$ untuk meningkatkan $\mathrm{pH}$ tanah. Penambahan kapur dolomit dilakukan dengan cara mencampurkan $2,25 \mathrm{~kg}$ kapur dolomit bersama $810 \mathrm{~kg}$ tanah untukdiinkubasi dan dijaga kelembabannya selama 14 hari. Setelah 14 hari, tanah yang telah diinkubasi bersama kapur dolomit diambil sebanyak $100 \mathrm{~g}$ sebagai sampel untuk dilakukan analisis $\mathrm{pH}$. Setelah peningkatan $\mathrm{pH}$ diketahui diberikan pupuk $\mathrm{KCl}$ ke dalampolybagyang telah berisi media. Pengisian media tanam dalam polybag dilakukan dengan cara mencampurkan $90 \mathrm{~kg}$ pupuk kandang kambing dan $810 \mathrm{~kg}$ tanah topsoil dengan perbandingan 9:1 (W/W) yaitu $9 \mathrm{~kg}$ tanah top soil dan $1 \mathrm{~kg}$ pupuk kandang kambing (Suhaila et al., 2013).

Penanaman dilakukan pada saat bibit telah memiliki tinggi yang seragam dan jumlah total daun pada bibit mencapai 4 daun atau lebih. Penanaman dilakukan dengan cara memindahkan bibit dari tray tanam atau polybag semai ke lubang tanam yang telah berisi Karbofuran 3\%. Jarak tanam antar polybagadalah $50 \mathrm{~cm}$ x $50 \mathrm{~cm}$. Penyulaman dilakukan 1 minggu setelah tanam (mst) pada tanaman yang mati atau tidak tumbuh normal.

Aplikasi pemupukan dilakukan pada saat tanaman berumur 7 hari setelah tanam (hst) dengan cara menaburkan pupuk NPK Mutiara (16:16:16), KCl, dan TSP secara melingkar disekitar tanaman (dibenamkan) sesuai dengan dosis perlakuan (Jumini etal., 2011). Pupuk urea diberikan secara bertahap, masing-masing $1 / 2$ dosis pada saat tanaman berumur 7 hst dan saat tanaman berumur 1 bulan setelah tanam (bst) sesuai dengan dosis perlakuan. Penyiraman tanaman dilakukan 2 kali sehari. Penyiraman tambahan dilakukan jika cuaca 
terasa panas. Hal ini dilakukan untuk menjaga kelembaban tanah.

Penyiangan dilakukan secara manualyaitu dengan mencabut gulma yang terdapat dalampolybagdengan tangan atau arit kecil. Pengendalian organisme pada tanaman cabai dilakukan dengan 2 cara yaitu secara kimiawi dan mekanik. pengendalian secara kimiawi dilakukan dengan cara menyemprot Insektisida berbahan aktif Profenofos 500g/L dan Imidakloprid $200 \mathrm{~g} / \mathrm{L}$ yang dikombinasikan dengan Fungisida Mankozeb satu kali dalam seminggu secara bergantian. Pengendalian secara mekanik dilakukan dengan dua cara yaitu dengan membunuh hama secara langsung dan menggunakan perangkap. Pengendalian mekanik menggunakan perangkap dilakukan untuk mengendalikan serangan lalat buah pada saat menjelang panen. Pengendalian lalat buah dilakukan dengan cara membuat perangkap lalat dari botol plastik bekas berukuran $600 \mathrm{~mL}$ yang di dalamnya dipasang bahan aktif Karbofuran 3\% (Furadan) dan Metileugenol 800 g/L (Patrogenol) sebanyak 4 botol yang diletakkan di empat sisi screenhouse. Selama pemasangan perangkap ini didapatkan lalat buah yang ada di screenhouse khususnya lalat jantan berjumlah hampir mencampai 268 ekor. Panen dilakukan pada saat buah telah berwarna merah. Panen dilakukan setiap minggu selama 6 minggu. Variabel yang diamati adalah tinggi tanaman $(\mathrm{cm})$, tinggi cabang dikotomus $(\mathrm{cm})$, diameter batang $(\mathrm{cm})$, lebar kanopi $(\mathrm{cm})$, panjang kanopi daun $(\mathrm{cm})$, luas kanopi daun (cm), umur berbunga (hst), umur panen (hst), jumlah buah total per tanaman (buah), bobot buah segar per tanaman $(\mathrm{g})$, panjang buah $(\mathrm{cm})$, panjang tangkai buah $(\mathrm{cm})$, diameter buah $(\mathrm{mm})$, bobot brangkasan segar $(\mathrm{g})$, bobot brangkasan kering (g). Data dianalisis secara statistik menggunakan uji $\mathrm{F}$ pada taraf $5 \%$. Perbandingan rata-rata antar perlakuan dilakukan dengan Duncan's Multiple Range Test (DMRT) pada taraf 5\% (Gomez and Gomez, 1984).

\section{HASIL DAN PEMBAHASAN}

Hasil analisis varian memperlihatkan bahwa perlakuan pupuk anorganik pada varietas cabai rakitan UNIB menunjukkan interaksi nyata pada variabel umur berbunga, jumlah total buah, dan diameter buah (Tabel 1). Pengaruh pupuk anorganik menunjukkan perbedaan nyata pada variabel diameter batang, umur berbunga dan, jumlah buah total. Pengaruh varietas cabai hibrida UNIB menunjukkan perbedaan nyata pada variabel pengamatan, tinggi cabang dikotomus, luas kanopi daun, panjang kanopi daun, diameter batang, umur berbunga, umur panen, jumlah total buah, bobot buah segar, diameter buah, panjang tangkai buah, dan panjang buah (Tabel 1). 
Tabel 1. Hasil analisis varians terhadap variabel pertumbuhan dan hasil cabai hibrida

\begin{tabular}{lrlrlll}
\hline \multirow{2}{*}{ Peubah } & \multicolumn{9}{c}{ F-hitung } \\
\cline { 2 - 6 } & \multicolumn{2}{c}{ Pupuk } & \multicolumn{2}{c}{ Interaksi } \\
\hline Tinggi tanaman & 3,07 & $\mathrm{~ns}$ & 0,12 & $\mathrm{~ns}$ & 1,58 & $\mathrm{~ns}$ \\
Tinggi cabang dikotomus & 0,90 & $\mathrm{~ns}$ & 25,00 & $*$ & 0,85 & $\mathrm{~ns}$ \\
Panjang kanopi daun & 1,70 & $\mathrm{~ns}$ & 4,82 & $*$ & 1,23 & $\mathrm{~ns}$ \\
Lebar kanopi daun & 0,11 & $\mathrm{~ns}$ & 2,27 & $\mathrm{~ns}$ & 0,93 & $\mathrm{~ns}$ \\
Luas kanopi daun & 0,13 & $\mathrm{~ns}$ & 6,21 & $*$ & 0,94 & $\mathrm{~ns}$ \\
Diameter batang & 6,48 & $*$ & 10,23 & $*$ & 0,63 & $\mathrm{~ns}$ \\
Umur panen & $0,84 \mathrm{~ns}$ & 5,12 & $*$ & 0,50 & $\mathrm{~ns}$ \\
Umur berbunga & 3,80 & $*$ & 3,95 & $*$ & 2,73 & $*$ \\
Jumlah buah total & 14,76 & $*$ & 11,04 & $*$ & 2,90 & $*$ \\
Diameter buah & 0,01 & $\mathrm{~ns}$ & 48,14 & $*$ & 2,78 & $*$ \\
Bobot buah segar & 1,36 & $\mathrm{~ns}$ & 13,39 & $*$ & 0,36 & $\mathrm{~ns}$ \\
Panjang buah & $1,81 \mathrm{~ns}$ & 298,55 & $*$ & 1,91 & $\mathrm{~ns}$ \\
Panjang tangkai buah & 1,20 & $\mathrm{~ns}$ & 139,81 & $*$ & 1,04 & $\mathrm{~ns}$ \\
Bobot berangkasan segar & 1,18 & $\mathrm{~ns}$ & 1,51 & $\mathrm{~ns}$ & 0,94 & $\mathrm{~ns}$ \\
Bobot berangkasan kering & $0,78 \mathrm{~ns}$ & $1,38 \mathrm{~ns}$ & $1,21 \mathrm{~ns}$ \\
\hline
\end{tabular}

Keterangan : ${ }^{*}=$ berpengaruh nyata pada taraf $5 \% ; \mathrm{ns}=$ bepengaruh tidak nyata pada taraf $5 \%$

Hasil analisis varian pada 15 peubah kuantitatif menunjukkan interaksi yang nyata antar pupuk anorganik dan varietas pada 3 peubah yaitu umur berbunga, diameter buah dan, jumlah buah total. Interaksi tidak terlihat nyata pada pada 12 peubah lainnya. Hal ini menunjukkan bahwa terdapat 12 respon pertumbuhan dan hasil yang sama pada tiga varietas cabai hibrida dengan berbagai aplikasi pupuk anorganik.

Tiga varietas cabai hibrida UNIB memberikan respon pertumbuhan dan hasil yang berbeda nyata pada setiap jenis pupuk anorganik yang diaplikasikan. Umur berbunga cabai hibrida yang paling cepat terlihat pada varietas UNIB C H65, yaitu pada umur 38,8 hst terdapat pada aplikasi pupuk Urea+KCl+TSP, berbeda nyata dengan aplikasi pupuk lainnya. Tetapi jika dipupuk dengan NPK Mutiara (16:16:16) varietas UNIB C H65 menghasilkan umur berbunga yang lebih lama dibandingkan varietas lainnya. Data rata-rata umur berbunga tiga varietas cabai hibrida UNIB pada setiap taraf pemupukan terlihat pada Tabel 2.

Tabel 2. Interaksi antara pupuk anorganik dan varietas cabe terhadap umur berbunga

\begin{tabular}{llll}
\hline \multirow{2}{*}{ Pupuk } & \multicolumn{3}{c}{ Varietas } \\
\cline { 2 - 4 } & UNIB C H73 & UNIB C H65 & UNIB C H13 \\
\hline NPK Mutiara (16:16:16) & $41,0 \mathrm{~A}$ & $50,8 \mathrm{~A}$ & $42,2 \mathrm{~A}$ \\
& (b) & (a) & (b) \\
Urea + KCl + TSP & $43,4 \mathrm{~A}$ & $38,8 \mathrm{~B}$ & $38,4 \mathrm{~A}$ \\
& (a) & (a) & (a) \\
1/2 dosis Urea + 1/2 dosis KCl + 1/2 dosis & $38,2 \mathrm{~A}$ & $44,2 \mathrm{~B}$ & $39,2 \mathrm{~A}$ \\
TSP + 1/2 dosis NPK Mutiara (16:16:16) & (a) & (a) & (a) \\
\hline
\end{tabular}

Keterangan : Angka-angka yang diikuti oleh huruf yang sama berpengaruh tidak nyata pada DMRT taraf 5\%. Notasi dengan huruf besar dibaca secara vertikal, sedangkan notasi dengan huruf kecil dibaca secara horizontal 
Cepat lambatnya umur berbunga tanaman cabai sangat dipengaruhi oleh unsur hara yang diserap oleh tanaman. Kandungan $\mathrm{K}_{2} \mathrm{O}$ yang dimiliki pupuk anorganik NPK Mutiara (16:16:16) pada dosis $300 \mathrm{~kg} / \mathrm{ha}$ sebesar $48 \mathrm{~kg} / \mathrm{ha}$. Jika melihat rekomendasi unsur hara yang dikeluarkan oleh Balitsa, $\mathrm{K}_{2} \mathrm{O}$ yang diperlukan tanaman cabai sebesar $100 \mathrm{~kg} / \mathrm{ha}$ pada musim penghujan dan $120 \mathrm{~kg} / \mathrm{ha}$ pada musim kemarau. Jumlah $\mathrm{K}_{2} \mathrm{O}$ yang dikandung pupuk NPK Mutiara (16:16:16) masih sangat kurang untuk mempercepat umur berbunga pada tanaman cabai. Sedangkan kandungan $\mathrm{K}_{2} \mathrm{O}$ yang terdapat pada aplikasi pupuk anorganik $1 / 2$ dosis Urea $+1 / 2$ dosis $\mathrm{KCl}+1 / 2$ dosis TSP $+1 / 2$ dosis NPK Mutiara sebesar $136,12 \mathrm{~kg} / \mathrm{ha}$, jumlah ini lebih besar dari anjuran yang diberikan oleh Balitsa sehingga mampu mempercepat pembungaan pada varietas UNIB C H73. Nurwanto et, al.,(2017) menyatakan ketersedian K yang tinggi dalam pupuk Kalium mampu mengurangi kerontokan bunga, dan meningkatkan jumlah bunga yang jadi pada saat pembudidayaan.

Jika dibandingkan dengan hasil penelitian yang dilakukan Supriyadi (2014) pembentukan bunga pada varietas UNIB C H73 lebih cepat 32,75 hstpada tanah ultisol di lahan dibandingkan tanah ultisol pada polybag dengan aplikasi pupuk yang sama (NPK Mutiara 16:16:16) yaitu 41 hst. Pengaruh lingkungan menjadi faktor dominan yang menyebabkan umur berbunga pada tanaman yang ditanam di lahan lebih cepat dibandingkan tanaman yang ditanam dalam polybag yang diletakan pada screen house. Tanaman cabai yang ditanam pada lahan menerima sinar matahari dan curah hujan lebih tinggi dibandingkan di rumah kawat. Selain itu aktifitas mikroorganisme penyerbukan lebih banyak terjadi pada lahan dibandingkan dirumah kawat.

Aplikasi pupuk anorganik menunjukkan pengaruh yang berbeda nyata pada varietas UNIB C H73 dan UNIB C H65. Jumlah buah total terbanyak dihasilkan varietas UNIB C H65 (61,8 buah) pada aplikasi pupuk anorganik Urea+KCl+TSP. Jika dibandingkan pada varietas UNIB C H13 jumlah buah total yang dihasilkan pada aplikasi pupuk yang sama menunjukkan respon yang berbeda nyata. Jumlah buah total yang dihasilkan oleh varietas UNIB C H13 lebih sedikit dibandingkan dua varietas lainnnya pada aplikasi pupuk yang sama (Urea+KCl+TSP). Data rata-rata jumlah buah total 3 varietas hibrida UNIB pada setiap taraf pemupukan terlihat pada Tabel 3 .

Hal yang mempengaruhi banyak tidaknya jumlah buah total cabai hibrida ialah unsur hara $\mathrm{P}$ yang diserap oleh tanaman. Unsur hara $\mathrm{P}$ merupakan unsur hara yang sangat mempengaruhi pembentukan buah pada tanaman. Kandungan unsur hara $\mathrm{P}_{2} \mathrm{O}_{5}$ yang terdapat pada pupuk anorganik TSP sebesar $230 \mathrm{~kg} / \mathrm{ha}$ dalam dosis aplikasi $500 \mathrm{~kg} / \mathrm{ha}$. Jumlah ini sudah lebih dari anjuran yang diberikan oleh Balitsa yaitu $138 \mathrm{~kg} \mathrm{P}_{2} \mathrm{O}_{5} / \mathrm{ha}$. Jumlah yang ini mampu meningkatkan jumlah buah total pada varietas UNIB C H65 dan UNIB C H73 
namun tidak mampu meningkatkan jumlah buah total varietas UNIB C H13. Pada fase generatif tanaman lebih cenderung memerlukan unsur hara $\mathrm{P}$ sebagai pembentukan bunga dan buah. Namun bila terjadi kekurangan unsur hara $\mathrm{P}$ pada fase generatif dapat menyebabkan produksi tanaman menjadi menurun serta menyebabkan fisiologi tanaman menjadi lemah yang dapat menyebabkan tanaman terserang penyakit (Lingga dan Marsono, 2007).

Tabel. 3. Data rata-rata interaksi pupuk anorganik dan varietras terhadap jumlah buah total

\begin{tabular}{|c|c|c|c|}
\hline \multirow{2}{*}{ Pupuk } & \multicolumn{3}{|c|}{ Varietas } \\
\hline & UNIB C H73 & UNIB C H65 & UNIB C H13 \\
\hline NPK Mutiara (16:16:16) & $\begin{array}{l}33,2 \mathrm{~B} \\
\text { (a) }\end{array}$ & $\begin{array}{l}25,8 \mathrm{~B} \\
\text { (a) }\end{array}$ & $\begin{array}{l}22,4 \mathrm{~A} \\
\text { (a) }\end{array}$ \\
\hline Urea+KCl+TSP & $\begin{array}{l}52,2 \mathrm{~A} \\
\text { (a) }\end{array}$ & $\begin{array}{l}61,8 \mathrm{~A} \\
\text { (a) }\end{array}$ & $\begin{array}{l}28,0 \mathrm{~A} \\
\text { (b) }\end{array}$ \\
\hline $\begin{array}{l}1 / 2 \text { dosis Urea }+1 / 2 \text { dosis } \mathrm{KCl}+1 / 2 \text { dosis } \\
\text { TSP }+1 / 2 \text { dosis NPK Mutiara }(16: 16: 16)\end{array}$ & $37,4 \mathrm{~B}$ & $34,0 \mathrm{~B}$ & $24,6 \mathrm{~A}$ \\
\hline & (a) & (a) & (a) \\
\hline
\end{tabular}

Berdasarkan penelitian Priyanto (2012) varietas UNIB C H13 menghasilkan jumlah buah lebih banyak (91,27 buah) pada percobaan di lapangan. Jika dibandingkan pada percobaan pot/polybag jumlah buah total yang dihasilkan pada varaietas UNIB C H13 masih sangat sedikit (22,4 buah) pada percobaan di lapangan. Varietas cabai hibrida memiliki kecocokan jika dibudidayakan dalam skala lapangan dikarenakan daya adaptasi yang sangat tinggi terhadap lingkungan.

Diameter buah tertinggi dihasilkan oleh varietas UNIB C H65 pada aplikasi pupuk anorganik Urea+KCl+TSP dengan rata-rata $0,694 \mathrm{~cm}$. Jika melihat dari data yang ditampilkan pada Tabel 4. Aplikasi pupuk tersebut menunjukan pengaruh yang berbeda tidak nyata dengan pupuk lainnya. Hal ini diduga karena faktor genetik yang dimiliki oleh varietas UNIB C H13 yang menyebabkan diameter buah berbeda tidak nyata pada aplikasi tiga jenis pupuk anorganik. Perbedaan bahan genetik yang membentuk individu hibrida. Misalnya, hibrida H73 adalah produk persilangan G7 (cabai besar) dan G3 (cabai keriting) yang menghasilkan hibrida semi-keriting (Ganefianti dan Fahrurrozi, 2013). Data rata-rata diameter buah 3 varietas hibrida UNIB pada setiap taraf pemupukan terlihat pada Tabel 4. 
Agitrop, Vol. 17 (2): 188 - 203

Tabel 4. Data rata-rata interaksi pupuk anorganik dan varietras terhadap diameter buah $(\mathrm{cm})$

\begin{tabular}{llll}
\hline \multirow{2}{*}{ Pupuk } & \multicolumn{3}{c}{ Varietas } \\
\cline { 2 - 4 } & UNIB C H73 & UNIB C H65 & UNIB C H13 \\
\hline NPK Mutiara (16:16:16) & $0,637 \mathrm{~A}$ & $0,687 \mathrm{~A}$ & $0,549 \mathrm{~A}$ \\
& (a) & (a) & (b) \\
Urea+KCl+TSP & $0,688 \mathrm{~A}$ & $0,694 \mathrm{~A}$ & $0,483 \mathrm{~A}$ \\
& (a) & (a) & (b) \\
1/2 dosis Urea + 1/2 dosis KCl + 1/2 dosis & $0,630 \mathrm{~A}$ & $0,691 \mathrm{~A}$ & $0,551 \mathrm{~A}$ \\
TSP +1/2 dosis NPK Mutiara (16:16:16) & (a) & (a) & (b) \\
\hline
\end{tabular}

Keterangan : angka-angka yang diikuti oleh huruf yang sama berpengaruh tidak nyata pada DMRT taraf 5\%. Notasi dengan huruf besar dibaca secara vertikal, sedangkan notasi dengan huruf kecil dibaca secara horizontal

Persilangan G7 dan G3 yang menghasilkan hibrida semi kriting mengakibatkan buah yang dihasilkan mengikuti bentuk tetuanya. Buah dari varietas ini rata-rata memiliki ukuran yang besar dan panjang. Aplikasi pupuk anorganik Urea+KCl+TSP merangsang genetik ini meghasilkan buah yang besar sehingga menghasilkan diameter buah yang besar. Pemberian pupuk NPK Mutiara (16:16:16) memberikan pengaruh yang berbeda nyata terhadap varietas UNIB C H133 dengan Diameter buah 0,549 cm lebih kecil dibandingkan varietas lainnya. Hal yang sama juga terjadi pada aplikasi pupuk anorganik Urea+KCl+TSP dan $1 / 2$ dosis Urea $+1 / 2$ dosis $\mathrm{KCl}+1 / 2$ dosis $\mathrm{TSP}+1 / 2$ dosis NPK Mutiara 16:16:16 yang menghasilkan diameter buah pada varietas UNIB C H13 rata-rata $0,483 \mathrm{~cm}$ dan $0,551 \mathrm{~cm}$ lebih kecil dibandingkan varietas lainnya. Hal ini dipengaruhi oleh faktor genetik besar kecilnya ukuran diameter buah juga dipengaruhi oleh ketertersediaan unsur hara $\mathrm{P}$ dan $\mathrm{K}$ di dalam tanah. Unsur hara $\mathrm{K}$ dan $\mathrm{P}$ yang diserap dari dalam tanah mempercepat laju respirasi pada tanaman yang mempengaruhi translokasi fotosintat yang sudah tersedia dari hasil fotosintesis dialokasikan ke buah menjadi lebih tinggi, sehingga ukuran buah yang terbentuk menjadi lebih besar termasuk diameter buah dan panjang buah (Wibowo et, al, 2016).

Jika dilihat dari hasil penelitian yang dilakukan Febriansyah (2013) diameter buah yang dihasilkan oleh varietas UNIB C H13 pada aplikasi pupuk anorganik NPK Mutiara (16:16:16) sebesar $0,549 \mathrm{~cm} /$ buah dari sebelumnya $0,483 \mathrm{~cm} /$ buah. Pada aplikasi pupuk yang sama pada varietas UNIB C H73 diameter buah yang dihasilkan mengalami peningkatan sebesar 0,637 cm/buah dibandingkan sebelumnya $0,633 \mathrm{~cm} /$ buah (Supriayadi, 2014). Besar kecilnya diameter buah dipengaruhi oleh ketebalan daging buah. Ketebalan kulit buah dipengaruhi oleh unsur hara P pada saat pengisian buah. Sinclair et al. (2001) menyatakan unsur hara $\mathrm{P}$ diserap dari larutan tanah dalam bentuk $\mathrm{HPO}_{4}{ }^{2-}$ dan $\mathrm{HPO}_{4}^{-}$. Unsur hara $\mathrm{P}$ membangun energi pembungaan dan perbaikan kualitas hasil tanaman cabai merah (Machay et, al., 2004). 
Hasil analisis varian menunjukkan respon pertumbuhan yang berbeda nyata pada peubah diameter batang pada tiga jenis pupuk anorganik yang diaplikasi. Pengaplikasian pupuk anorganik Urea+KCl+TSP menghasilkan diameter batang rata-rata 0,610 $\mathrm{cm}$ yang berbeda tidak nyata dengan pupuk anorganik $1 / 2 \mathrm{Urea}+\mathrm{KCl}+\mathrm{TSP}+1 / 2 \mathrm{NPK}$ tetapi pada aplikasi pupuk anorganik NPK Mutiara (16:16:16) menunjukan respon pertumbuhan yang berbeda nyata. Pada aplikasi pupuk NPK Mutiara (16:16:16) diameter batang yang dihasilkan berbeda nyata terhadap aplikasi pupuk lainnya dengan rata-rata $0,529 \mathrm{~cm}$. Jika dibandingkan dengan penelitian yang dilakukajn oleh Supriyadi (2014) pada aplikasi pupuk NPK Mutiara (16:16:16) diameter batang yang dihasilkan saat ini masih sangat kecil dibandingkan penelitian tersebut dengan diameter batang mencapai $0,863 \mathrm{~cm}$. Data rata-rata setiap varieabel pengamatan disajikan pada Tabel 5.

Tabel 5. Data rata-rata pertumbuhan tanaman cabai pada tiga jenis pupuk anorganik.

\begin{tabular}{lccccccc}
\hline \multicolumn{1}{c}{ Pupuk Anorganik } & $\begin{array}{c}\text { DB } \\
(\mathbf{c m})\end{array}$ & $\begin{array}{c}\text { TCD } \\
(\mathbf{c m})\end{array}$ & $\begin{array}{c}\text { TT } \\
(\mathbf{c m})\end{array}$ & $\begin{array}{c}\text { LBKD } \\
(\mathbf{c m})\end{array}$ & $\begin{array}{c}\text { PKD } \\
(\mathbf{c m})\end{array}$ & $\begin{array}{c}\text { LKD } \\
(\mathbf{c m})\end{array}$ & $\begin{array}{c}\text { UP } \\
(\mathbf{h s t})\end{array}$ \\
\hline NPK Mutiara (16:16:16) & $0,529 \mathrm{~b}$ & 44,6 & 97,1 & 75,3 & 85,1 & 133,5 & 87 \\
Urea+KCl+TSP & $0,610 \mathrm{a}$ & 44,7 & 109,1 & 74,3 & 95,8 & 149,7 & 83 \\
$\begin{array}{l}1 / 2 \text { dosis Urea + 1/2 dosis KCl } \\
+1 / 2 \text { dosis TSP + 1/2 dosis }\end{array}$ & $0,622 \mathrm{a}$ & 44,8 & 104,8 & 77,1 & 95,5 & 144,3 & 83 \\
NPK Mutiara (16:16:16) & & & & & & & \\
\hline
\end{tabular}

Keterangan : angka-angka pada kolom yang sama yang diikuti huruf sama berbeda tidak nyata pada DMRT taraf 5\%. Angka-angka yang tidak diikuti huruf berpengaruh tidak nyata terhadap aplikasi pemupukan. DB: Diameter Batang, TCD: Tinggi cabang Dikotomus, LBKD: Lebar Kanopi Daun, PKD: Panjang Kanopi Daun, LKD: Kuas Kanopi Daun, UP: Umur Panen.

Pertumbuhan diameter batang sangat mempengaruhi jumlah buah total dan bobot buah segar yang dihasilkan oleh suatu tanaman. Aplikasi pupuk anorganik Urea+KCl+TSP menghasilkan diameter batang rata-rata $0,610 \mathrm{~cm}$ dengan jumlah buah total rata-rata 61,8 buah (Tabel 4) dan bobot buah segar yang mencapai 201,91 g/tanaman (Tabel 6). Silahooy (2008) menyatakan penambahan diameter batang berhubungan dengan fungsi unsur K untuk meningkatkan kadarsclerenchyma pada batang. Sclerenchyma mempunyai fungsi memberi penebalan dan kekuatan pada jaringan batang sehingga tanaman lebih kuat atau tidak mudah rebah. Penambahan sclerenchyma menyebakan diameter batang juga bertambah besar. Ukuran diameter batang yang semakin besar mempengaruhi jumlah air dan nutrisi yang masuk ke tanaman semakin banyak. Pertumbuhan tinggi tanaman sangat dipengaruhi oleh jumlah nutrisi yang diberikan. Aplikasi pupuk anorganik Urea+KCl+TSP mampu meningkatkan tinggi tanaman rata-rata 109,1 cm dibandingkan pupuk lainnya. Pertumbuhan tanaman yang tinggi menghasilkan tinggi cabang dikotomus yang jauh dari permukaan tanah. Cabang dikotomus yang jauh dari permukaan tanah mampu mengurangi percikan air 
yang merupakan sumber infeksi cendawan pada buah cabai (Sofiaridan Kirana, 2017). Panjang dan luas kanopi daun yang dihasilkan pada aplikasi pupuk anorganik Urea+KCl+TSP rata-rata 95,8 $\mathrm{cm}$ dan $149,7 \mathrm{~cm}$ lebih tinggi dibandingkan aplikasi pupuk lainnya, walaupun menunjukkan respon pertumbuhan yang berbeda tidak nyata. Aplikasi pupuk anorganik tersebut mampu mempercepat umur panen 83 hst lebih cepat dibandingkan aplikasi pupuk anorganik majemuk.

Setiap jenis pupuk yang diaplikasikan pada tiga varietas cabai hibrida UNIB secara tunggal ataupun majemuk menunjukkan respon pertumbuhan yang berbeda tidak nyata pada fase vegetatif terhadap enam peubah yang diamati (Tabel 5). Aplikasi pupuk tunggal yang diberikan secara penuh pada tiga varietas cabai hibrida menghasilkan tinggi tanaman tertinggi yaitu 109,1 cm dibandingkan pupuk lainnya dengan panjang dan luas kanopi yang mencapai 95,8 cm dan 144,3 cm. Namun jika pupuk anorganik tunggal dan pupuk anorganik majemuk diaplikasikan bersamaan dengan dosisi setengahnya pada tiga varietas cabai hibrida menghasilkan diameter batang terbesar 0,622 $\mathrm{cm}$ dengan tinggi cabang dikotomus mencapai 44,8 cm dan lebar kanopi mencapai 95,8 cm. Aplikasi pupuk anorganik majemuk menghasilkan tinggi tanaman dan tinggi cabang dikotomus lebih rendah rata-rata $97,1 \mathrm{~cm}$ dan 44,6 cm dibandingkan aplikasi pupuk lainnya. Namun jika dibandingkan dengan hasil penelitian Supriyadi (2014) pada aplikasi pupuk NPK Mutiara (16:16:16) tinggi cabang yang dihasilkan rata-rata 32,05 $\mathrm{cm}$ lebih rendah dibandingkan dengan hasil penelitian saat ini. Tinggi tanaman yang dihasilkan penelitian yang dilakukan Supriyadi (2014) rata-rata84,20 $\mathrm{cm}$ masih sangat rendah jika dibandingkan dengan penelitian saat ini $(97,1 \mathrm{~cm})$ pada aplikasi pupuk anorganik NPK Mutiara (16:16:16).

Tabel. 6 Data rata-rata pengamatan fase generatif pada aplikasi tiga jenis pupuk anorganik.

\begin{tabular}{lccccc}
\hline \multicolumn{1}{c}{ Pupuk Anorganik } & $\begin{array}{c}\text { PTB } \\
(\mathbf{c m})\end{array}$ & $\begin{array}{c}\text { BBS } \\
(\mathbf{g})\end{array}$ & $\begin{array}{c}\text { PB } \\
(\mathbf{c m})\end{array}$ & $\begin{array}{c}\text { BBRS } \\
(\mathbf{g})\end{array}$ & $\begin{array}{c}\text { BBRK } \\
(\mathbf{g})\end{array}$ \\
\hline NPK Mutiara (16:16:16) & 4,94 & 110,29 & 12,2 & 99,6 & 54,5 \\
Urea + KCl + TSP & 4,92 & 150,49 & 11,6 & 134,1 & 69,7 \\
1/2 dosis Urea + 1/2 dosis KCl + 1/2 dosis & 4,78 & 122,86 & 11,7 & 112,9 & 62,8 \\
TSP + 1/2 dosis NPK Mutiara (16:16:16) & & & &
\end{tabular}

Keterangan : PTB : Panjang Tangkai Buah, PB : Panjang Buah, BBS : Bobot Buah Segar, BBRS : Bobot Berangkasan Segar, BBRK : Bobot Berangkasan Kering.

Setiap jenis pupuk yang diaplikasikan pada 3 varietas cabai hibrida UNIB secara tunggal ataupun majemuk menunjukkan respon hasil yang berbeda tidak nyata pada fase generatif terhadap lima peubah yang diamati (Tabel 6). Aplikasi pupuk majemuk menghasilkan panjang tangkai dan panjang buah lebih besar dibandingkan aplikasi pupuk lainnya dengan rata-rata $4,94 \mathrm{~cm}$ dan $12,2 \mathrm{~cm}$. Namun jika dibandingkan dengan hasil 
penelitian Supriyadi (2014) pada aplikasi pupuk NPK Mutiara (16:16:16) panjang buah yang dihasilkan rata-rata $13,65 \mathrm{~cm}$ lebih tinggi dibandingkan penelitian saat ini yang hanya mencapai $12,2 \mathrm{~cm}$. Aplikasi pupuk anorganik NPK Mutiara (16:16:16) pada tanaman cabai hibrida UNIB menghasilkan bobot buah segar tertinggi 110,29 g yang lebih rendah dibandingkan dengan hasil penelitian Supriyadi (2014) yang mencapai 311,29 g. Bobot berangkasan segar dan kering yang dihasilkan pada aplikasi pupuk tunggal lebih besar dibandingkan pupuk lainnya dengan rata-rata $134,1 \mathrm{~g}$ dan $69,7 \mathrm{~g}$. Namun jika dibandingkan dengan hasil penelitian Supriyadi (2014) pada aplikasi pupuk anorganik NPK Mutiara (16:16:16) bobot berangkasan segar dan bobot berangkas kering yang dihasilkan rata-rata 261,20 $\mathrm{g}$ dan 89,38 $\mathrm{g}$ lebih tinggi dibandingkan hasil penelitian saat ini.

Pemberian pupuk anorganik pada cabai varietas UNIB C H13, C H65 dan, C H73 memberikan pengaruh yang berbeda nyata terhadap pertumbuhan vegetatif dan generatif tanaman cabai. Data rata-rata dari setiap variabel pengamatan disajikan pada Tabel 7.

Tabel. 7. Data rata-rata pertumbuhan cabai hibrida terhadap aplikasi pupuk anorganik

\begin{tabular}{cccccccc}
\hline $\begin{array}{c}\text { Varietas cabai } \\
\text { hibrida }\end{array}$ & $\begin{array}{c}\text { DB } \\
(\mathbf{c m})\end{array}$ & $\begin{array}{c}\text { LKD } \\
(\mathbf{c m})\end{array}$ & $\begin{array}{c}\text { TCD } \\
(\mathbf{c m})\end{array}$ & $\begin{array}{c}\text { UP } \\
(\mathbf{h s t})\end{array}$ & $\begin{array}{c}\text { PTB } \\
(\mathbf{c m})\end{array}$ & $\begin{array}{c}\text { PB } \\
(\mathbf{c m})\end{array}$ & $\begin{array}{c}\text { BBS } \\
(\mathbf{g})\end{array}$ \\
\hline UNIB C H73 & $0,626 \mathrm{a}$ & $128,3 \mathrm{~b}$ & $49,2 \mathrm{a}$ & $82,7 \mathrm{~b}$ & $5,42 \mathrm{a}$ & $14,97 \mathrm{a}$ & $201,91 \mathrm{a}$ \\
UNIB C H65 & $0,622 \mathrm{a}$ & $133,3 \mathrm{~b}$ & $45,3 \mathrm{~b}$ & $83,6 \mathrm{~b}$ & $3,77 \mathrm{~b}$ & $6,68 \mathrm{c}$ & $84,39 \mathrm{~b}$ \\
UNIB C H13 & $0,514 \mathrm{~b}$ & $166,0 \mathrm{a}$ & $41,1 \mathrm{c}$ & $91 \mathrm{a}$ & $5,46 \mathrm{a}$ & $14,02 \mathrm{~b}$ & $97,33 \mathrm{~b}$ \\
\hline
\end{tabular}

Keterangan : angka-angka pada kolom yang sama yang diikuti huruf sama berbeda tidak nyata pada DMRT taraf 5\%. DB : Diameter batang, LKD : Luas Kanopi Daun, UP : Umur Panen, PTB : Panjang Tangkai Buah, PB : Panjang Buah, BBS : Bobot Buah Segar.

Varietas UNIB C H73 menghasilkan diameter batang tertinggi rata-rata $0,626 \mathrm{~cm}$ yang lebih besar dibandingkan varietas lainnya. Ukuran diameter batang yang besar mempengaruhi jumlah air dan nutrisi yang dialirkan keseluruh bagian tanaman, sehingga semakin banyak air dan nutrisi yang masuk kedalam jaringan, akan mempertebal dan memperkokoh batang tanaman cabai untuk menopang pertumbuhannya (Saputra et, al., 2013). Diameter batang yang besar menghasilkan cabang dikotomus yang tinggi dan kokoh. Tinggi cabang dikotomus yang dihasilkan oleh varietas UNIB C H73 rata-rata 49,2 cm lebih tinggi dibandingkan varietas lainnya. Cabang dikotomus yang berjarak jauh dari permukaan tanah mengurangi infeksi cendawan pada buah yang disebabkan oleh percikan air (Sofiari dan Kirana, 2007). Berkurangnya jumlah buah yang rusak dan busuk akibat cendawan menghasilkan buah cabai yang baik dan segar. Buah cabai yang baik dan segar ditandai dengan bobot buah segar dan jumlah buah total yang dihasilkan. Bobot buah segar yang dihasilkan varietas UNIB C H73 rata-rata 201,91 g lebih berat dibandingkan varietas lainnya.

Jika dibandingkan dengan hasil penelitian yang dilakukan oleh Supriyadi (2014) bobot 
buah segar yang dihasilkan rata-rata 261,20 g yang tidak jauh berbeda dengan bobot buah segar yang dihasilkan saat ini (201,99 g). Jumlah buah total yang dihasilkan varietas UNIB C H73 rata-rata 52,2 buah (Tabel 3) cukup rendah jika dibandingkan dengan varietas UNIB C H65 dengan rata-rata 61,8 buah. jumlah huah total yang dihasilkan pada saat ini $(52,2$ buah), masih sangat rendah jika dibandingkan dengan hasil penelitian yang dilakukan oleh Siregar (2014) rata-rata 86,38 buah. Panjang buah yang dihasilkan varietas UNIB C H73 rata-rata 14,97 cm lebih tinggi dibandingkan varietas lainnya. Jika melihat hasil penelitian Supriyadi (2014) panjang buah yang dihasilkan varietas UNIB C H73 rata-rata 13,65 cm lebih rendah dibandingkan dengan hasil penelitian saat ini.

Varietas UNIB C H65 menghasilkan diameter batang rata-rata $0,622 \mathrm{~cm}$ yang berbeda tidak nyata demngan varietas UNIB C H73. Umur berbunga yang dihasilkan oleh varietas UNIB C H65 lebih lama 38,8 hst dibandingkan dengan varietas lainnya. Namun untuk umur panen yang dihasilkan varietas UNIB C H65 mengahsilkan umur panen yang lebih cepat 83,6 hstdibandingkan dengan varietas UNIB C H13. Jika dibandingkan dengan hasil penelitian yang dilakukan oleh Febriansyah (2013) umur berbunga yang dihasilkan tidak terlalu berbeda jauh dengan penelitian saat ini yaitu 38,66 hst dengan umur panen yang dihasilkan sangat jauh lebih cepat dibanding kan saat ini yaitu 79,66 hst. Tinggi cabang dikotomus yang dihasilkan varietas UNIB C H65 sangat berbeda nyata dengan varietas lainnya rata-rata 45,3 cm. Sofiari dan Kirana (2007) menyatakan tinggi cabang dikotomus yang jauh dari permukaan tanah mampu mengurangi percikan air yang merupakan sumber infeksi cendawan pada buah cabai. Jumlah buah total yang dihasilkan varietas UNIB C H65 lebih banyak dibandingkan varietas lainnya dengan rata-rata 61,8 buah (Tabel 3). Selain menghasilkan jumlah buah total yang lebih tinggi diameter buah yang dihasilkan varietas ini juga lebih besar dibandingkan varietas lainnnya dengan rata-rata 0,694 cm (Tabel 4). Bobot buah segar yang dihasilkan varietas UNIB C H65 rata-rata 84,39 g lebih rendah dibandingkan varietas UNIB C H73. Jika dibandingkan dengan penelitian yang dilakukan Febriansyah (2013) tinggi cabang dikotomus yang dihasilkan rata-rata 25,66 cm lebih rendah dibandingkan dengan penelitian saat ini. Selain diameter buah yang dihasilkan pada penelitian saat ini mengalami peningkatan $0,6 \%$ dari sebelumnya yang mencapai $0,631 \mathrm{~cm}$.

Panjang tangkai buah yang dihasilkan oleh varietas UNIB C H65 rata-rata 3,77 HST lebih rendah dibandingkan varietas lainnya. Varietas UNIB C H65 menghasilkan panjang buah C H65 rata-rata $6,68 \mathrm{~cm}$ lebih rendah dibandingkan varietasa lainnya. Jika dibandingkan dengan hasil penelitian yang dilakukan oleh Febriansyah (2013) panjang tangkai buah yang dihasilkan 3,13 cm lebih rendah dibandingkan hasil saat ini. panjang buah yang dihasilkan pada saat ini mengalami peningkatan $0,79 \%$ dibandingkan peneitian 
sebelumnya rata-rata $5,89 \mathrm{~cm}$.

Varietas UNIB C H13 menghasilkan diameter batang rata-rata $0,514 \mathrm{~cm}$ lebih kecil dibandingkan varietas lainya. Umur berbunga yang dihasilkan varietas UNIB C H13 38,4 hstlebih cepat dibandingkan varietas lainnya. Umur panen yang dihasilkan varietas ini $91 \mathrm{hst}$ lebih lambat dibandingkan varietas lainnya. Tinggi cabang dikotomus yang dihasilkan varietas ini berbeda nyata dengan varietas lainnya dengan rata-rata $41,1 \mathrm{~cm}$ dengan luas kanopi daun mencapai $166 \mathrm{~cm}$ lebih luas dari varietas lainnya. Jumlah buah yang dihasilkan varietas ini rata-rata 28 buah dengan bobot buah segar mencapai 97,33 g. Panjang tangkai buah yang dihasilkan varietas UNIB C H13 rata-rata 5,46 cm lebih panjang dibandingkan varietas lainnya dengan respon hasil yang berbeda tidak nyata pada varietas UNIB C H73.Hasil pertumbuhan panjang buah berbeda nyata dengan varietas lainnya dengan panjang buah rata-rata $14,02 \mathrm{~cm}$.

Jika melihat dari hasil penelitian yang dilakukan Supriyadi (2014) diameter batang yang dihasilkan varietas UNIB C H13 pada penelitian tersebut $0,863 \mathrm{~cm}$ lebih tinggi dibandingkan hasil saat ini. Namun tinggi cabang dikotomus yang dihasilkaan rata-rata $32.05 \mathrm{~cm}$ lebih rendah dibandingkan hasil saat ini $(41,1 \mathrm{~cm})$. Bobot buah segar pertanaman yang dihasilkan penelitian tersebut mencapai $277,30 \mathrm{~g}$ lebih tinggi dari penelitian saat ini $(97,33 \mathrm{~g})$ dengan panjang buah mencapai $13,11 \mathrm{~cm}$ lebih rendah dari hasil saat ini $(14,02 \mathrm{~cm})$.

\section{KESIMPULAN}

Aplikasi pupuk anorganik tunggal Urea+KCl+TSP $(250 \mathrm{~kg} / \mathrm{ha}+500 \mathrm{~kg} / \mathrm{ha}+400 \mathrm{~kg} / \mathrm{ha})$ pada varietas UNIB C H65 menghasilkan jumlah buah total tertinggi yaitu 61,8 buah. Aplikasi pupuk anorganik Urea+KCl+TSP meningkatkan pertumbuhan dan hasil tanaman cabai hibrida ditunjukkan dengan tinggi tanaman tertinggi yaitu 109,1 cm, kanopi daun terluas yaitu 145,9 cm, umur berbunga tercepat $38,8 \mathrm{hst}$, diameter buah terbesar 0,694 cm, jumlah buah total terbanyak rata-rata 61,8 buah dan bobot buah segar yang mencapai 150.49 g serta bobot berangkasan segar dan kering terberat rata-rata $134,1 \mathrm{~g}$ dan $69,7 \mathrm{~g}$. Varietas UNIB C H73 menghasilkan diameter batang tertinggi $0,626 \mathrm{~cm}$, tinggi cabang dikotomus tertinggi 49,22 cm, umur panen lebih cepat 82,7 hst, panjang tangkai buah terpanjang 5,42 cm, panjang buah 14,97 lebih panjang dan, bobot buah segar terberat 201,91 g.

\section{DAFTAR PUSTAKA}

Harpenas, A dan R. Dermawan. 2010. Budidaya Cabai Unggul. Jakarta: Penebar Swadaya.

Febriansyah, 2013. Karakterisasi Variabel Kualitatif dan Kuantatif Cabai Hibrida Hasil Persilangan Dialel. Skripsi. Program Studi Agroekoteknologi, Jurusan Budidaya 
Pertanian Fakultas Pertanian. Universitas Bengkulu, Bengkulu (tidak dipublikasikan).

Ganefianti, D.W., Fahrurrozi, and Y, Armadi. 2017. Hybrid Performance Testing of Chili Pepper (Capsicumannuum L.) for Resistance to Yellow Leaf Curl Begomovirus.SABRAO Journal of Breeding and Genetics, 49(2):179-191.

Ganefianti, D.W and Fahrurrozi. 2013. Heterosis and Combining Ability in Complete Diallel Cross of Seven Chili Pepper Genotypes Grown in Ultisol. AGRIVITAJournal of Agricultural Science, 40(2): 360-370.

Gomez, K.A and A.A. Gomez, (1984). Statistical Procedures for Agricultural Research (2 ed.). New York : John wiley and Sons.

Lingga, P dan Marsono. 2005. Petunjuk Penggunaan Pupuk. Swadaya Grup: Jakarta.

Mulyani dan Kartasapoetra, 2002. Pupuk dan Cara Pemupukan. Jakarta: Rineka Cipta.

Nurwanto., SoedradjadA,R, dan S,Niken. 2017. Aplikasi Berbagai Dosis Pupuk Kalium dan Kompos terhadap Produksi Tanaman Cabai Rawit (Capsicumfrutescens L.). JurnalAgritrop, 15(2): 181-193.

Prasetya, M.E. 2014. Pengaruh Pupuk NPK Mutiara dan Pupuk Kandang Sapi terhadap Pertumbuhan dan Hasil Tanaman Cabai Merah Keriting Varietas Arimbi (Capsicumannuum L.). Jurnal AGRIFOR,(2): 191-198.

Priyanto, A. 2012. Heterosis Dan Hetrobeltiosis dan Hasil Cabai dalam Persilangan Dialel. Skripsi. Fakultas Pertanian Universitas Bengkulu, Bengkulu (tidak dipublikasikan).

Pusat Data dan Sistem Informasi Pertanian, 2016. Oulook Komoditas Pertanian Sub Sektor Hortikultura Cabai Merah 2016. Oulook Cabai. Jakarta: Dinas Pertanian.

Raziliano., Yetti, H, dan Yoseva, S. 2015. Pemberian Abu Serbuk Gergaji dan Pupuk Urea, TSP, $\mathrm{KCl}$ terhadap Pertumbuhan dan Produksi Tanaman Cabai (CapsicumAnnuum L.) di Lahan Gambut. JOM FAPERTA, 2(1): 201-203.

Saputra., Idwar, M, dan Deviona. 2013. Evaluasi Keragaan Tujuh Genotipe Cabai (Capsicum Annuum L.) diLahan Gambut. Skripsi. Fakultas Pertanian. UNRI (tidak dipublikasikan).

Silahooy, C. 2008. Efek Pupuk KCl dan SP-36 Terhadap Kalium Tersedia, Serapan Kalium dan Hasil Kacang Tanah (Arachis hypogaea L.) pada Tanah Brunizem. Bul. Agron. 36(2): $126-132$.

Sinclair, A and Catling, P. M. 2001. Cultivating the Increasingly Popular Medicinal Plant, Goldenseal: Review and Update. American Journal of Alternative Agriculture, 16(3): 131-140.

Sirappa, M.P dan Senewa, R. 2014. Kajian Penggunaan Pupuk Organik dan Anorganik pada Tanaman Cabai Varietas Tanamo di Dataran Rendah Kabupaten Seram Bagian Barat. Jurnal Budidaya Pertanian, 10(1): 41-47.

Siregar, F.K. 2014. Uji Keunggulan Cabai Hibrida Perakitan UNIB di Lahan Gambut. Skripsi. Program Studi Agroekoteknologi, Jurusan Budidaya Pertanian Fakultas 
Agitrop, Vol. 17 (2): 188 - 203

Pertanian. Universitas Bengkulu, Bengkulu (tidak dipublikasikan).

Sofiari, E. dan Kirana, R. 2007. Heterosis dan Heterobeltiosis pada Persilangan 5 Hibrida dengan Metode Dialel. J.Hort, 17(2): 111-117.

Supriyadi. 2014. Uji Keunggulan Cabai Hibrida Perakitan Unib Dilahan Ultisol dan Histosol. Skripsi. Program Studi Agroekoteknologi, Jurusan Budidaya Pertanian Fakultas Pertanian. Universitas Bengkulu, Bengkulu (tidak dipublikasikan).

Tarigan, S dan Wiryanta, W. 2007. Bertanam Cabai secara Intesif. Jakarta: Swadaya Grup.

Wibowo, A., Armaini, dan Wardati. 2016. Uji Tiga Genotipe Cabai Merah (Capsicumannuum L.) pada Formulasi Pupuk di Lahan Gambut. J. JOM FAPERTA, 3(1): 201-203.

Widiyono, W dan Hidayati, N. (2005). Periode Kritis Tanaman Cabai Merah Besar (Capsicum annnuum L. var. long cltilli) pada Perlakuan Cekaman Air. Indonesian Journal of Biology, 3(9): 389-396. 